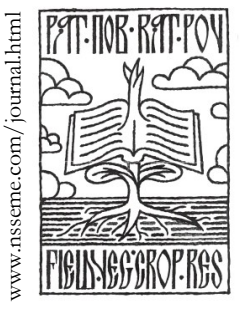

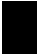

\title{
Tolerance of Wheat Varieties Seedlings by Glyphosate Accelerated Degradation
}

\author{
Zoran Jerković · Željana Prijić · Radivoje Jevtić · \\ Branka Orbović · Mirjana Lalošević
}

\begin{abstract}
received: 18 July 2014, revised: 24 December 2014, accepted: 26 December 2014
published online: 6 February 2015

(C) 2014 IFVC

doi:10.5937/ratpov51-6472

Summary: Lengths of seedlings aboveground parts of nine wheat varieties grown in greenhouse were reduced by $4-20 \%$. They were tested during April at around $20^{\circ} \mathrm{C}$ after twice daily treatments with glyphosate based herbicide $\left(0.5 \mathrm{ml}\right.$ in 11 water solution, $0.5 \mathrm{dl}$ on $\left.0.5 \mathrm{~m}^{2}\right)$. When results of permanent artificially and daily lighted trials were compared, four groups of varieties were recognized same as was when near isogenic lines containing different leaf rust resistance genes (Lr NILs) were focused in winter. Growth of variety Pobeda decreased more when seedlings were not permanent lighted which confirmed the common herbicide effect. Tolerance of other varieties was again explained by enzymatic degradation of glyphosate and chlorophyll inhibition by consequential phosphorus acids. Varieties Simonida, Tavita and Rapsodia were similar by reaction to glyphosate as Lr 1 and Lr 21 NILs. NS 40S contained Lr 3a with increased hydrolytic stability compared to $\mathrm{Lr} 24$ but able to cleave external single phosphorus for the difference of Lr 19 or Lr 29. Their final effect was similar to previous stated of Lr 15 NIL during the winter. Varieties Gora and Metka had gene Lr 19, Enigma Lr 29 while Ilina Lr 24. Focusing herbicide residua transfer in seed probability, accounting optimal time for recovering ability of chlorophyll and temporary higher temperatures necessary for Lr genes even parasite free activity the varieties Gora, Metka and Enigma appeared to be possible solution for glyphosate apply near wheat heading in semiarid regions.
\end{abstract} Key words: glyphosate, herbicides, Lr gene, seedlings, tolerance, wheat variety

\section{Introduction}

Glyphosate was pronounced to be the herbicide of the century (Duke \& Powles 2009) mostly according to environmental influence and for plants adequacy of residua in soil, while effect was linked to inhibition of 5enolpyruvil-shikamate-3-phosphate synthase, disrupting shikimic acid pathway (Duke \& Powles 2008). Consequential luck of aromatic amino acids was trough phosphatase decreased synthesis influential on energy transfer by ATP confirmed trough $\mathrm{CO}_{2}$ accumulation and relist before reduced chlorophyll fluorescence (Yaniccari et al. 2012). For eliminating pesticides negative effects in crops three strategies were predicted: evaluated gene introduction already realized by facilitated shicamate acid pathway, its modification or degradation (Castle et al. 2004).

\footnotetext{
Z. Jerković* · R. Jevtić · B. Orbović · M. Lalošević

Institute of Field and Vegetable Crops, 30 Maksima Gorkog, 21000 Novi Sad, Serbia

e-mail: zoran.jerkovic@nsseme.com

Ž. Prijić

University Megatrend, Faculty for Biofarming, Maršala Tita 39, 24300 Bačka Topola, Serbia
}

Similarity in gluten, fungi cell wall and some of the pesticides structure involving sulfur initiated investigations in which some of the race specific wheat leaf rust resistance genes appeared to be influential on dithiocarbamate and phtalamide accelerated degradation (Jerkovic et al. 2012). In the next study when thiamethoxam or thiacloprid based insecticides were applied at Lr near isogenic lines (Lr NILs) similar growth decrease was identified as well as positive effect when adequate Lr genes for accelerated release of sulfur were absent, explained through fast hydrolysed nitrogen units for additional nutrition (Jerkovic et al. 2014a). By differences in growth of adequate NILs when focused were artificial continual and natural lighted trial and glyphosate was applied large overdosed at seedlings, Lr genes were classified in four groups: 6-10\% ( $\mathrm{Lr}$ 1, Lr 15, Lr 21), 12-15\% (Lr 16, Lr 19, Lr 21, Lr $29)$ and $29 \%$ of $\operatorname{Lr} 24$ while results of $\operatorname{Lr} 9, \operatorname{Lr} 2 \mathrm{a}$ and $\operatorname{Lr} 22 \mathrm{~b}$ Nils were vice versed indicating common effect. Herbicide in proposed dose linearly prolonged latency period or decreased reaction type to Puccinia triticina isolate of those NILs. Yellowing of first leaves was heat and drought stress dependent and opposite when genes from ineffective fourth group were control (Jerkovic et al. 2014b). 
The molecular markers for majority of approximately $69 \mathrm{Lr}$ genes (Huerta Espino et al. 2011) were reported (Purnhauser et al. 2000) while further were extended by other ones mostly at $2 \mathrm{D}$ (Dholakia et al. 2013) or 7D chromosomes (Huseinova et al. 2013) where various Lr genes were located (Mc Intosh 1998). Diagnostic value of molecular markers regarding vertical resistance was discussed by Sefing et al. (2011). It was hypothetical that more of them had to be similar by relative prolonged activity achieved through hydrolytic stability as Lr 15, pronounced to be inadequate for practical glyphosate tolerance application at all. Simultaneously, molecular markers for recognizing tolerant varieties become insufficient because different located $\mathrm{Lr}$ genes were not defined respecting characters discovered by novel methods. However, similar method as described in the above chapter appeared to be the solution for extensive preliminary recognizing of the wheat varieties tolerant to glyphosate.

\section{Material and Methods}

In the trial for estimation of single glyphosate influence, nine wheat varieties were simultaneously sown in pots $(30 \times 25 \times 15 \mathrm{~cm})$. Density was approximately one plant per $50 \mathrm{~mm}^{2}$ while distance between rows was $2 \mathrm{~cm}$. Varieties were grown in the greenhouse at average air temperature around $20^{\circ} \mathrm{C}$ during March and April achieved by cover reducing $70 \%$ of heath and $10 \%$ of light. Daily watering of the soil from below pots was stopped two days before glyphosate was applied. Near equal plants in the time when second leaf started to appear where selected with aim to avoid possible errors due to different initial growth between treated and control plants of the varieties. Equal four trials by content and distribution of varieties they were halved by cover and sprayed once or twice daily successively with 0.5 $\mathrm{ml}$ glyphosate in 11 water solution $0.5 \mathrm{dl}$ on $0.5 \mathrm{~m}^{2}$ using the hand sprayer simulating dose of $0.5 \mathrm{l} / \mathrm{ha}$ recommended for practice. One of the pots where the glyphosate was applied twice was permanent artificially lighted from source $1 \mathrm{~m}$ distanced from above. At least five different treated plants of each variety were considered representative sample for up ground parts length estimation performed fifteen days after the first treatment, while average values were used for effect determination. LGR value of control lines represented average divided sum of first leaf and stem with second one length fifteen days from treatment, while yellowing of the first leaves was also determined five days previous by scale 1-5 (segments of $20 \%$ of area) or on second one simultaneous.

According to formula for growth equalizing (Jerkovic et al. 2014a) in the recent study possible errors were below $2 \%$ and were not significant for differentiation of the glyphosate effects as was in the trial when Lr NILs were studied. Growth reduction when trial was daily lighted were not all proportional at same herbicide dose explained by different light intensity in particular parts of greenhouse, but were with results of triple sprayed Lr NILs. Furthermore, when the results of Lr NILs were compared, three analogue groups of genes responsible for glyphosate degradation were again recognized (Tab. 1). Variety Pobeda exposed characteristic as fourth one confirming presence of nonspecific Lr genes presence. Lr genes in varieties Rapsodia, Simonida, Tavita and NS 40S had to be classified in the first group by growth reduction below $6 \%$. By similarity to second one, Gora and Metka were as Lr 19 while Enigma as was Lr 29 NIL. The Lr genes in the varieties were also previously recognized by parasite interactions with different isolates through effect on LP or RT and comparison with NILs (Jerkovic, unpublished data). The largest difference in growth reduction of $20 \%$ between permanent and natural lighted trial also confirmed the presence of the gene as was in Lr 24 NIL in the variety Ilina. By recently performed trial the stated hydrolytic instability of its gene was confirmed by relative increased late yellow area of first leaves after prolonged dry period from common for other lines $40 \%$ to $60 \%$ (2 or 3 ) to $80 \%$ (4). It was recognized on variety NS 40 S but earlier than on Ilina, while effect of $\operatorname{Lr} 15$ was excluded according to studies of gluten degradation (Jerkovic et al. 2013). Lr 3a proposed to be in the variety, had to be particular, intermediate hydrolytic stable with more extended approach ability in comparison to discussed genes from the second group but not able to cleave last single external phosphorus residua. Such, could be explained the often same effect to parasite isolate as Lr 1 Jerkovic et al. 2013) as well as was not expected enhanced resistance when accumulated. Stated characteristic was supported by relative increased LGR to 0.67. No effect of similar genes to Lr 24 like were Lr 2a and Lr 9 in NILs on glyphosate degradation was linked to luck of approach ability to targeted element these time external linked single phosphorus. At last mentioned character and cleaved linkage strength appeared to be correlated while approach ability was found to be independent. Such, nine mine groups of to parasite races specific effective Lr genes were predicted to already exist according to characters of $\mathrm{Lr}$ genes recognized trough parasite free interactions studies.

When herbicide was applied on lines found to be resistant to glyphosate, the resistance to Puccinia spp. was increased (Anderson et al. 2005) more than when Lr NILs were focused former. Similar appearance was recognized when soybean rusts were such interacted (Feng et al. 2005). 
Table 1. Growth reduction by glyphosate of wheat varieties seedlings, LGR after 15 and maximum yellowing of first leafs after 10 days

\begin{tabular}{|c|c|c|c|c|c|c|c|}
\hline Variety & $\begin{array}{c}\text { LGR } \\
\text { of } 4^{\text {th }} \\
\text { treatment } \\
\text { control }\end{array}$ & $\begin{array}{c}1 . \\
2 \times 0.51-h a \\
\text { Perm. } \\
\text { artific. } \\
\text { lighted } \\
\mathrm{T}: \mathrm{K}\end{array}$ & $\begin{array}{c}2 \mathrm{x} \\
0,5 \text { l-ha } \\
\mathrm{T}: \mathrm{K}\end{array}$ & $\begin{array}{c}\text { Difference } \\
\text { between } \\
1^{\text {st }} \text { and } 2^{\text {nd }} \\
\text { treatment }\end{array}$ & $\begin{array}{c}1 \mathrm{x} \\
0,5 \text { l-ha } \\
\mathrm{T}: \mathrm{K}\end{array}$ & $\begin{array}{c}1 \mathrm{x} \\
0,5 \text { l-ha } \\
\mathrm{T}: \mathrm{K}\end{array}$ & $\begin{array}{c}\text { Yellowing } \\
\text { of } 4^{\text {th }} \\
\text { treated } \\
\text { plants }\end{array}$ \\
\hline Simonida & 0.67 & 0.86 & 0.92 & 0.06 & 0.89 & 0.98 & 3 \\
\hline Rapsodija & 0.57 & 0.85 & 0.89 & 0.04 & 0.95 & 0.97 & 3 \\
\hline Tavita & 0.64 & 0.92 & 0.98 & 0.06 & 0.90 & 0.95 & 3 \\
\hline NS 40S & 0.67 & 0.73 & 0.79 & 0.06 & 0.80 & 0.87 & 4 \\
\hline Enigma & 0.64 & 0.82 & 0.95 & 0.13 & 0.86 & 0.94 & 3 \\
\hline Gora & 0.71 & 0.76 & 0.90 & 0.14 & 0.76 & 0.83 & $2-3$ \\
\hline Metka & 0.65 & 0.81 & 0.92 & 0.11 & 0.81 & 0.81 & $2-3$ \\
\hline Ilina & 0.67 & 0.69 & 0.89 & 0.20 & 0.70 & 0.85 & 4 \\
\hline Average & 0.67 & 0.81 & 0.91 & 0.09 & 0.84 & 0.90 & \\
\hline Pobeda & 0.61 & 0.85 & 0.76 & -0.09 & 0.86 & 0.90 & 2 \\
\hline
\end{tabular}

However, the effect of all specific Lr genes had to be ensured by parasite entrance across consequential water deficit in cell. Mostly the enhancement of the resistance with respect of durability of the trait was achieved by combinations of nonspecific and specific Lr genes (Kolmer 1996, Oelke \& Kolmer 2004). The appearance was linked to temporary water deficit consequential in lower infection efficiency or decreased reaction type (De Vallavieille-Pop et al. 1995, Niks \& Dekens 1991, Jerkovic et al. 2013b). Genes from different groups according to glyphosate degradation Lr 9, Lr 19 and Lr 24 were to parasitic isolate same effective (Jerkovic et al. 1992). By nowadays studies, the appearance had to be explained by same ratio of adequate linked targeted elements in the cell wall (Harder \& Chong 1984, Koegel et al. 1988).

The tolerance based on different distribution of glyphosate recognized when Lolium perene was grown in Missouri (Nandula et al. 2008) could be related to relative decreased LGR or increased SAGR, characters dependable of environment conditions and controlled by various complementary nonspecific Lr genes (Jerkovic et al. 2012). Variety Rapsodia with relative highest decreased LGR to 0.57 similar as was of NS 8041 (Jerkovic et al. 2014a) also had these genes obvious accumulated with Lr 22b (Jerkovic et al. 2013b). Respecting aforementioned explanation of tolerance the second leaves of these genotypes were expected to be effected by glyphosate, but it was opposite after 15 days confirming Lr 1 gene stable activity while Lr 24 and additional various effective one had to be in the mentioned line.

When recognized interactions of $\mathrm{Lr}$ genes and pesticides were assumed, the Lr 16 and Lr 29 appeared to be behind most or all nowadays recognized accelerated degradations of pesticides. Such, one could conclude that they had to be stable and present in wheat varieties. If assortment was handled according to sustainable economic Pucinia triticina control based on varieties containing different Lr genes, suggested by Jerkovic et al. (2013a), unfortunately than, potential practical tolerance to this herbicide in semiarid region should be also temporary in all or only partially applicable. According to nowadays stated pathways, respecting at first more time for original herbicide residua elimination before transfer in seed, consequences on growth and then facilitated recovering of chlorophyll, glyphosate apply near wheat heading become solution because of temporary expected enough increased temperature or drought stress necessary for Lr 29 or Lr 19 genes activity even parasite free. The enzymes for magnesium relist from former sulphate were recognized and facilitated faster chlorophyll synthesis after fungicide application (Jerkovic et al. 2012), while from phosphate they were not indicated respecting active elements amount in herbicide and dosage. According to related current studies as well as stated residua in seed of glyphosate ready crops in 2013 by Biotech, it was considered no possibility for residua degradation out of wheat cell. 


\section{Conclusions}

The specific Lr genes accumulations expected to be more effective by simultaneous various glyphosate residua degradations or of genes as was Lr 15 were not recognized. Assuming the all of the aspects, varieties like were Gora, Metka and Enigma were predicted to be practically useful for multiple pest reduction by one treatment in semiarid regions before wheat heading respecting more time for original residua elimination and light intensity. According to results of the variety Pobeda the time for suggested Lr genes activity in parasite free conditions facilitated by drought or heath stress had to be within approximately ten days after treatment. Treatment of variety Ilina appeared to be risky according to possible no effect at all. On others containing more hydrolytic stable gene like Simonida, Rapsodia and Tavita the negative effect of glyphosate have to be more avoided but expected consequence was not original residua containing linked carbon to phosphorus transfer in seed as well as their relative more frequented presence than by using of all other effective Lr genes.

\section{References}

Anderson, J.A., \& Kolmer, J.A. (2005). Rust control in glyphosate tolerant wheat following application of the herbicide glyphosate. Plant Disease 89: 1136-1142.

Browder, L.E. (1985). Parasite: Host: Environment specificity in the cereal rusts. Ann. Rev. Phytopathol., 23: 201-222.

Castle, L.A., Siehl, D.I., Gordon, B., Patten, P.A., Chen, Y.H., \& Bertain, S. (2004). Discovery and directed evaluation of a glyphosate tolerance gene. Science 304: 1151-1154.

Chen, X., \& Line, R.F. (1995). Gene action in wheat cultivars for durable, high temperature, adult plants resistance and interactions with race specific, seedling resistance to Puccinia striiformis. Phytopathology 85: 567-572.

De Vallavieille-Pop, C., Huber, L., Leconte, M., \& Goyeau, H. (1995). Comparative effects of temperature and interrupted wet periods on germination, penetration and infection of Puccinia recodita f.sp. tritici and P. striiformis on wheat seedlings. Ecology and Epidemiology 86: 409-420.

Dholakia, B.B., Rajwade, A.V., Hosmani, P., Khan, R.R., Chavan, S., Reddy, D.M.R., Lagu, M.D., Bansal, U.K., Saini, R.G., \& Gupta, V.S. (2013). Molecular mapping of leaf rust resistance gene $L r 15$ in hexaploid wheat. Molecular Breeding 31: 743-747.

Duke, S.O., \& Powles, S.B. (2008). Glyphosate: A once in a century herbicide. Pest Manag. Sci. 64(4): 319-325.

Duke, S.O., \& Powles, S.B. (2009). Glyphosate- resistant crops and weeds: now and the future. Ag Bio Forum 12(3): 12-18.

Feng, C.C., Baley, G.J., Clinton, P.W., Bunkers, J.G., Alibhai, F.M., Paulitz, C.T., \& Kidwell, K.K. (2005). Glyphosate inhibits rust diseases in glyphosate-resistant wheat and soybean. Proceedings of the National Academy of Sciences of the United States of America 102(48): 17290-17295.

Harder, D.E., \& Chong, P. (1984), Structure and physiology of haustoria. In: AP Roelfs, WR Bushnell (eds.), Cereal rust. Vol. I, Academic Press, pp 431-473.
Huerta-Espino, J., Singh, P.P., Germain, S., McCallum. B.D., Park, R.F., Chen, W.Q., Bhardwey, S.C., \& Goheay, H. (2011). Global status of wheat leaf rust caused by Puccinia triticina. Euphytica 179: 143-160.

Huseynova, I.M., Guliyeva, F.B., Rustamova, S.M., Jalal, A., \& Aliyev, J.A. (2013). PCR-based molecular markers linked to the leaf rust resistance gene Lr19 in different bread wheat cultivars. Advances in Biological Chemistry 3: 153-158.

Jerkovic, Z. (1992). Identifying genes for Puccinia recondite f.sp. tritici resistance in wheat lines. J. of Genetics and Breeding 46: 163-166.

Jerković Z., \& Jevtic R. (2012). A solution for economical and safe wheat protection from parasites. Proceedings of ECOconference, Safe food, 97-102.

Jerkovic, Z., \& Prijic, Z. (2012a). Leaf rust specific resistance genes effect on degradation of fungicides with sulfur. Plant protection 63(1): 279, 29-35.

Jerkovic, Z, Prijic, Z, \& Djuric, V. (2013). Effect of accumulated resistance genes to Puccinia triticina on transfer of seed proteins. Ratar. Povrt. 50: 60-64.

Jerkovic, Z., Jevtic R., Lalosevic M., \& Prijic Z. (2013a). Integrated protection from prevalent wheat pathogens in semiarid regions. Journal of agricultural sciences 58(1): 1-18.

Jerkovic, Z., Prijic, Z., Djuric, V., Jevtic, R., \& Lalosevic, M. (2013b). Functions of Lr genes beside reduction of Puccinia triticina. Ratar. Povrt. 50: 6-12.

Jerkovic Z., Prijic Z., Jevtic R., \& Lalosevic, M. (2014). Interaction of two neonicotinoid insecticides and $\mathrm{Lr}$ genes focusing wheat growth and residua. Plant Prot. Sci., received in May.

Jerkovic Z, Prijic Z, Jevtic R, Orbovic, B., \& Lalosevic, M. (2014a). Lr genes facing glyphosate considered by residua, influence on wheat growth and leaf rust development. J. Plant Dis. Protect., received in May.

Jolivet, P., Bergeron, E., \& Kein, P. (1992). Oxidation of Elemental Sulfur and Sulfite by Chloroplasts. PhytonAnn. Rei Bot., Horn 32: 59- 62

Kolmer J.A. (1996). Genetics of resistance to wheat leaf rust. Annu. Rev. Phytopathol. 34: 435-455.

Mishra, A.N, Kaushal, K., Yadav S.R., Shriheker, G.S., \& Pandey, H.N. (2005). A leaf rust resistance gene, different from Lr 34 associated with leaf tip necrosis in wheat. Plant Breeding 124(5): 517-519.

Niks, R.E., \& Dekens, R.G. (1991). Prehaustorial and posthaustorial resistance to wheat leaf rust in diploid wheat seedlings. Phytopathology 81: 847-851.

Oelke, L.M. \& Kolmer, J.A. (2004). Characterization of leaf rust resistance in hard red spring wheat cultivars. Plant Dis. 88: 1127-1133.

Purnhouser, L, Gylai, G., Csosz, M., Hesky, L., \& Mesterhazy, A., (2000). Identification of Leaf Rust Resistance Genes in Common Wheat bv Molecular Markers. Acta Phytopathol. Entomol. Hung. 35(1): 31-36.

Serfing, A., Kramer, I., Lind, V., Shliphake, E. \& Ordojn, F. (2011). Diagnostic value of molecular markers for $L r$ genes and characterization of leaf rust resistance of German winter wheat cultivars with regard to the stability of vertical resistance. Eur. J. Plant Pathol. 130(4): 559-575.

Nandula, V. K., Reddy K.N. Poston D.H., Rimando A.M. \& Duke S.O. (2008). Glyphosate Tolerance Mechanism in Italian Ryegrass (Lolium multiflorum) from Mississippi. Weed Science 56(3): 344-349.

Yaniccari, M., Tambussi, E., Istilart, C., \& Castro, A.M., (2012). Glyphosate effects on gas exchange and chlorophyll fluorescence responses of two Lolium perenne L. biotypes with differential herbicide sensitivity. Plant Physiol. Biochem. 57: 210-217. 


\section{Tolerantnost sejanaca sorti pšenice preko ubrzane degradacije glifosata}

\section{Zoran Jerković · Željana Prijić · Radivoje Jevtić · Branka Orbović · Mirjana Lalošević}

Sažetak: Dužine nadzemnih delova sejanaca devet sorti pšenice gajenih u staklari bile su redukovane 4-20\%. Testirane su pri temperaturama oko $20^{\circ} \mathrm{C}$ tokom proleća posle dva dnevno uzastopna tretmana herbicidom na bazi glifosata $\left(0,5 \mathrm{ml} \mathrm{u} 11\right.$ vodenog rastvora, $0,5 \mathrm{dl}$ na $\left.0,5 \mathrm{~m}^{2}\right)$. Na osnovu razlika između stalno veštački i dnevno osvetljenog ponavljanja prepoznate su četiri grupe sorti, što je potvrdilo rezultate dobijene kod izogenih linije različitih gena otpornosti prema prouzrokovaču lisne rđe (NIL) testiranih tokom zime. Rast sorte Pobeda bio je usporeniji kada nije bila permanentno osvetljena te je prepoznat uobičajen efekat herbicida. Tolerantnost drugih sorti je bila povezana sa ubrzanom degradacijom glifosata te uticajem posledične fosforne kiseline na inhibiciju hlorofila. Sorte Rapsodija, Simonida i Tavita su po reakciji prema herbicidu bile slične Lr 1 i Lr 21 liniji. Ubrzano žućenje lista NS 40S bilo je zavisno od gena Lr 3a neuticajnog na poslednje fosforne residue nakon otpuštanja kiseonika, dok je sličan efekat hidrolitički najstabilnijeg Lr 15 u NIL isključen na osnovu analiza uticaja na degradaciju glutena. Na osnovu pomenutih kriterijuma, sorte Gora i Metka su sadržale Lr 19, Enigma Lr 29 a Ilina Lr 24. Poštujući pre svega više vremena za eliminaciju originalnih rezidua herbicida blizu klasanja, česte temperature uslove povoljne za aktivnost Lr gena, posledice na rast te brži oporavak hlorofila, za tretman u to doba u semiaridnim regionima, sorte s Lr genima kao Gora, Metka i Enigma su prepoznate kao moguće praktično rešenje. Tretman sorte Ilina je rizičan usled očekivanog izostanka efekta a ostalih usled rezidua.

Ključne reči: glifosat, herbicidi, Lr geni, sejanci, sorte pšenice, tolerantnost 